\title{
Politics versus Economics Philosophical Reflections on the Nature of Corporate Governance
}

\author{
Vincent Blok ${ }^{1,2}$ \\ Published online: 3 August 2019 \\ (C) The Author(s) 2019
}

\begin{abstract}
In this article, we philosophically reflect on the nature of corporate governance. We raise the question whether control is still a feasible ideal of corporate governance and reflect on the implications of the epistemic insufficiency of economic institutions with regard to grand challenges like of global warming for our conceptualization of corporate governance. We first introduce the concept of corporate governance from the perspective of economics and politics. We then trace the genealogy of the concept of governance based on a selective reading of Giorgio Agamben's work, who has pointed at two interdependent paradigms of governance in the Christian tradition, and apply his categories in the context of corporate governance. We finally engage in a critical reflection on the concept of corporate governance and develop four characteristics of corporate governance that can guide future conceptual as well as empirical research in the field of corporate social responsibility of economic institutions.
\end{abstract}

Keywords Corporate governance · Corporate social responsibility · Giorgio Agamben · Global warming · Wicked problems

\section{Introduction}

Increasingly, it is acknowledged that firms are not only economic institutions but at the same time moral institutions that contribute to society at large; they embody strategies and operations that involve moral decisions regarding the good or right way of production and consumption of their products and services. The core of Corporate Social Responsibility (CSR) policies of firms lies in their commitment to perform ethically in business life. CSR is however nothing straight-forward and poses several challenges.

Vincent Blok

vincent.blok@wur.nl

1 Management Studies Group, Wageningen University (The Netherlands), Hollandse Weg 1, 6707

KNWageningen, The Netherlands

2 Philosophy Group, Wageningen University (The Netherlands), Wageningen, Netherlands 
On the one hand, CSR can be seen as a corporate approach to integrate economic, social and environmental challenges in the business operations (Dahlsrud 2008). On the other hand, it raises all kinds of new questions regarding international equity, intergenerational justice, interspecies justice, free rider problems etc. (WCED 1987; Jamieson 2002). While the performance of corporate responsible behaviour presupposes that we know what is right and wrong in business life, many different stakeholders have different ideas about the moral problems and the scope of the social responsibility of economic institutions to address these problems. For a company like Neslé, CSR may consist in cleaner production and consumption processes (e.g. waste reduction, sustainable sourcing and recycling), while environmental NGO's may question the role of companies in the Western capitalist system. For a company like Unilever, CSR may consist in the increase of welfare conditions of animals that are used for food products, while animal welfare NGO's may question the role of animal production and consumption in general. The different value frames held by different societal actors poses a challenge for CSR implementation.

These challenges also occur at the level of the production processes of companies. Current production and consumption patterns - think of nanoparticles in food products, batteries in cell-phones and plutonium to power pacemakers - can be expected to impact future generations in a way that firms can never experience, predict or manage. Their foresight of future developments is fundamentally limited while their current knowledge of responsible solutions is insufficient and may always have unintended negative consequences. The lack of foresight and possibility of unexpected negative side effects reveal the epistemic insufficiency of economic institutions regarding the good or right way of production and consumption, while CSR policies of economic actors presuppose that they know what is right and wrong in business life. In other words, CSR managers operate in a world of epistemic insufficiency, i.e. a world in which there is no certainty about the possible effects of their interventions to take responsibility (De Martino 2011).

While the different value frames of stakeholders and the epistemic insufficiency of CSR managers make clear that CSR poses several challenges to the commitment to ethics in business life, the reality of these challenges also makes clear why economic institutions ought to commit to CSR. This raises the question who is in charge to engage economic institutions to engage in CSR. A first possible response consists in the idea that economic institutions themselves are able to address these challenges. CSR related governance mechanisms like sustainability standards and codes of conduct can be seen as successful instruments developed by economic institutions in order to enhance and secure more corporate social behaviour (cf. Andersen and Skjoett-Larsen 2009; Mamic 2005). A second possible response consists in the call for political action by governmental institutions to enhance and secure more corporate social behaviour by the introduction of new rules and regulations, whether or not on a global level. In both responses, it is self-evidently presupposed that we are currently 'out of control' and that control can be established and secured again by more established forms of public or private forms of governance. The question is however whether 'control' is still a feasible ideal of governance if we acknowledge the differences between the value frames of different stakeholders and the epistemic insufficiency of economic institutions regarding the good or right way to produce and consume. In this article, we raise the question what implications our epistemic insufficiency regarding this unknown and unknowable future has for corporate governance of social responsibility.

While corporate governance has been researched from several perspectives, ranging from self-regulation (Gond et al. 2011) to relational governance (Midttun 2005) and from new 
governance (Moon 2002) to performative governance codes (Blok 2017), the nature of 'governance' within corporate governance is still under-researched. A first complication in this respect is the relation between governance and CSR. CSR can be seen as a form of governance while governance itself could also be seen from the perspective of CSR (Idowu 2010). A second complication is the tendency to reduce the ethical question about right and wrong corporate responsible behaviour in business life to matters of governance frameworks and techniques. In this article, we philosophically reflect on the nature of corporate governance and on its consequences for CSR policies of economic institutions.

One way to open up the concept of corporate governance for philosophical reflection is by tracing the different meanings it has in history. Historical analysis can help us to question the selfevidence of the current association of governance and control, to deconstruct the presupposed concepts that always already structure our understanding of corporate governance, and to explore the sedimentary conceptual structures which show themselves in the words and notions we selfevidently use in our understanding of the governance of economic institutions. In this, we are indebted to Giorgio Agamben's The Kingdom and the Glory, which contains an intellectual history of the genealogy of the Western concept of governance. In this book, Agamben points at two interdependent paradigms of governance in the history of the Western world; kingdom and governance, sovereignty and economy, law and order (Agamben 2009, 2011). Agamben's philosophical project as a whole - Homo Sacer - can be read already as a philosophy of governance, namely as a philosophy of human life as it is included and at the same time excluded by political power (Agamben 1998). But because we are mainly interested in a positive concept of corporate governance, our philosophical reflections in this article do not consider Agamben's philosophy as a whole, ${ }^{1}$ but examine his genealogy of the concept of governance only in light of our effort to develop such a positive concept of corporate governance of social responsibility. This strategy is legitimate, as Agamben's philosophy of human life is notoriously abstract and nowhere explicitly considers governance in more applied fields like business ethics and philosophy of management, while he himself framed his book as genealogy of economy and government. This strategy explains why we do not provide a full account of Agamben's philosophy of human life in this article, but instead, provide a philosophical reflection on the nature of corporate governance in discussion with a selective reading of Agamben's genealogy of governance, in order to articulate a positive philosophical concept of corporate governance that can inform our understanding of CSR policies of economic institutions. ${ }^{2}$

In section one, we introduce the concept of corporate governance by exploring the economical and the political responses to the call for governance mechanisms in order to enhance and secure more corporate social behaviour. In section two, we review these two responses from the perspective of Agamben's genealogy of the concept of governance and apply his categories in the context of corporate governance of CSR policies. In section three, we engage in a philosophical reflection on the concept of governance that enhances and secures firm's commitment to corporate social behaviour. To this end, we develop four characteristics of a positive concept of corporate governance that can guide future conceptual as well as empirical research in this field.

\footnotetext{
${ }^{1}$ On the one hand, this would require an in-depth engagement with Agamben's philosophy as a whole, which is beyond the scope of this article. On the other hand, it is questionable what would be the added value of such an account, as Agamben himself never reflected on the corporate environment as particular context of application of his conceptuality.

${ }^{2}$ In our conscious selective reading of Agamben's genealogy of the concept of governance, we follow the strategy of eminent colleagues like Jessica Whyte (2013). For a critical instroduction in Agamben's work, see de la Durantaye (2009).
} 


\section{Corporate Governance and the Perspectives of Economics and Politics}

Corporate Governance is traditionally defined as a system by which the tasks and responsibilities within a firm are divided by both informal as well as formal mechanisms for directing and controlling the business objectives, the strategy and the operations of the firm (Abor and Adjasi 2007; Uhlaner et al. 2007; Roelofsen et al. 2015). Although Corporate Governance traditionally concerns the governance of the relation between the firm and its shareholders, and mainly focusses on financial control (revenue streams, market share, return on investment etc.), nowadays it includes other stakeholders as well and focusses on social and environmental objectives, next to financial objectives (sustainability, integrity, ethics etc.) (Abor and Adjasi 2007). In contemporary conceptualizations of corporate governance, it is therefore defined "as the system by which companies are directed and controlled and as a set of relationships between a company's management, its board, its shareholders and its other stakeholders" (European Commission 2010).

Corporate Governance can be seen as an instrument to enhance and secure responsible behaviour by economic institutions (Aguinis and Glavas 2012; Taneja et al. 2011; Jones 2009; Kallio 2007). There are various mechanisms of corporate governance that can be deployed by firms, like integrating CSR objectives in strategy development (Melewar and Karaosmanoglu 2006), the alignment of resource management (human resources, financial resources etc.) and CSR objectives (Filatotchev et al. 2006), the embedding of CSR objectives in a shared vision and the core values that constitute the organisational culture of the firm (Uhlaner et al. 2007), the monitoring of responsible behaviour by the introduction of codes of conduct and accountability reports (Filatotchev et al. 2006) etc. (Roelofsen et al. 2015).

The development of a broader perspective on corporate governance corresponds with wider developments in society. Traditionally, a strict distinction was made between the role and function of political actors - governance by the state as creation and maintenance of the political order - and economic actors - corporate governance by firms as creation and maintenance of the economic order. This distinction originates from Aristotle, who proposed a strict opposition between the private sphere of the house and the public sphere of the state (Aristotle 1944). ${ }^{3}$ In the so-called network society, however, the monopoly of the state to produce social regulation and judicial norms is no longer self-evident. ${ }^{4}$ It is increasingly replaced by a more complex network of non-state actors (firms, NGO's etc.) which are themselves loci of political activity (Castells 2000). This trend is strengthened by increasing complexity and globalisation. Because the primary responsibility for economic, socio-cultural and environmental aspects is allocated to different actors in society - the profit sector on the one hand and governmental organisations, NGOs and civil society on the other - it is argued that the governance of complex societal problems like global warming presuppose the active involvement of and partnership with society (Hens and Nath 2003; Blok 2014). With this, it involves the transfer of governance responsibilities from national governments to global

\footnotetext{
${ }^{3}$ One can question whether such a strict dichotomy can ever be encountered in real life and whether both spheres are not always intertwined, as we will argue in the next section with the help of Agamben's genealogy of the concept of governance. Nonetheless, we explore this dichotomy in this section because on the one hand, it helps to contrast the traditional Aristotelian concept of the duality of governance with its modern conceptualization in the network society, and, on the other hand, because contemporary debates on CSR still rely on these distinctions as we will see.

${ }^{4}$ Another way to frame the current context is by referring to Zygmunt Bauman's concept of liquid modernity, which indicates the fluidity of social positions of social actors in the current age (Bauman 2002).
} 
networks of multiple actors like Multinational Enterprises (MNE's) and global NGO's. With these trends a new type of governance emerges. Such political arrangements beyond the nation state and beyond its authoritative power to enforce the law, which instead rely primarily on non-hierarchical forms of steering and non-coercive power, can be understood as governance without government. An example of this emerging type of governance can be found in the collaboration between the World Wildlife Fund (WWF) and Unilever, who developed a longterm program for sustainable fisheries. This initiative, which is known as the Marine Stewardship Council, is a certification scheme that enhances sustainable behaviour of suppliers, fisheries and seafood shops.

One can critically argue that this modern concept of governance without government leads to a sovereignty of the market. Sovereign parliamentary and legislative power of the nation state is becoming recessive and is increasingly dominated by the market power of globally operating Multinational Enterprises; increasingly, states become dependent on market actors, which challenge the idea of the sovereignty of the state; increased levels of privatization, deregulation and marketization transformed the relation between the sovereign state and economic actors significantly over the years. Accordingly, we may argue that instead of a sovereignty over the market, we nowadays see a sovereignty of the market.

In times of crisis, this ability of economic actors to take responsibility becomes questionable. At the micro level, self-regulation by economic actors becomes questionable if one considers corporate scandals like Volkswagen's manipulation of pollution emissions tests in the US notwithstanding all kinds of corporate environmental policies. At the meso level, we see a structural negative impact of industries on the environment. At a macro level, economic actors are sometimes seen as 'externalisation machines', which makes CSR a contradiction in its own terms (Bakan 2005). The European Agricultural sector is for instance responsible for around $10 \%$ of GHG emissions, but corporate actors do not invest in climate smart agriculture because they have no incentive to do so.

These crises raise all kinds of questions regarding the sovereignty of the market and call for a new political sovereignty over the market. This means that it is assumed that political action is needed to enhance and secure corporate responsible behaviour. It is either called for political CSR, i.e. a political legitimation of economic actors by incorporating deliberative democratic practices in corporate governance (Scherer and Palazzo 2011). Or it is called for a bigger role of political governance as authoritative enforcement of corporate responsible behaviour by the introduction of new rules and regulation (Assländer and Curbach 2017). This call for the rehabilitation of the role of state regulation seems to be legitimate, as corporates have the tendency to serve their own interests, while national or even global governance is needed to serve the commons.

The question is, however, whether political actors can govern and control the market in the globalised and complex world we currently live in. Or is it the other way around that economic actors control the state, as political actors are influenced by the lobby activities of market actors and are influenced by the financial market of credit providers, ratings agencies etc. This 'paradox of regulation' shows the interdependency and interconnectedness of sovereign states and economic actors (Majone 1994; Haines 2011). This paradox leads to the question whether the traditional opposition between the sovereign power of the Nation state and the economic power of economic institutions is not a mere pre-supposition that never existed in reality. If such a classical opposition is merely a supposition, we can no longer call for political CSR or 
for the rehabilitation of the role of political governance. On the contrary, it raises questions regarding the nature of this interrelation between sovereign states and economic actors (Tempels et al. 2017). How do we have to conceptualize governance in this context and what are the consequences for corporate governance of economic institutions?

In the next section, we turn to the intellectual history of the concept of governance by Giorgio Agamben to answer these questions. On the one hand, Agamben can help us to trace the presupposed distinction and even antachonism between political and economic governance in the philosophical and theological tradition. Agamben enables us on the other hand to reflect on the interrelation between political and economic governance and can inform our philosophical concept of corporate governance, because he rejects such a strict dichotomy.

\section{Agamben's Genealogy of Governance and its Application in Corporate Governance Practices}

Instead of taking a position in the debate whether there is a sovereignty of the market or a sovereignty over the market, we philosophically reflect on the two types of governance and their interrelation in this article. To this end, we consult The Kingdom and the Glory, a book on the genealogy of the concept of governance by Giorgio Agamben. In this book, Agamben asks for "the ultimate structure of the governmental machine of the West" and argues that the two types of sovereign political governance and economic governance originate from two dominant paradigms in Christian theology, namely political theology and economic theology (Agamben 2011).

Even for readers who are not familiar with the Christian tradition, the difference between the two paradigms in theology can easily be understood. One of the traditional theological problems was how to reconcile the unicity and sovereign power of God with the trinity of the Father, the Son and the Holy Spirit, and with this, the reconciliation of the absolute and transcendent being of God with his providential and rescendent organization and administration of the world via his Son and the Holy Spirit (Agamben 2007). Political theology, on the one hand, concentrates on the nature of God and asks for his unicity, transcendence and sovereign power. This leads to a theory of the sovereignty of God. This paradigm of Christian theology is called political theology, because the theory of the sovereignty of God is juridico-political - God governs the world through the institution of universal rules, principles and norms, as opposed to the execution of this sovereign power by the application of these principles in management practices - and leads to contemporary theories of sovereignty.

Economic theology, on the other, concentrates on Gods relation to the created world. Oikonomia, as the Greeks understood it, is far removed from our contemporary understanding of economics, but concerns household management (Deslandes 2018; Blok 2019). This administrative paradigm defines oikonomia originally. While oikonomia originally concerns the administration of the household as it is opposed to politics as governance of public life (Aristotle 1944), the economic theologians take the word oikonomia to designate the immanent order of the administration of divine life, and the governance of its creatures, i.e. God's divine plan of salvation. The difference between sovereignty and economy is that the first is ontological - it concerns the being of God - while the second concerns God's praxis - it concerns his administration and management of human life on Earth. According to Agamben, this administration is not dependent on a set of (sovereign) rules or principles, but is the result 
of situational and pragmatic considerations that can be different in different situations (Agamben 2011: 17-18). "Oikonomia is presented here as a functional organization, an administrative activity that is bound only to the rules of the ordered functioning of the house (or of the company in question)" (Agamben 2011: 18). While Aristotle sees this oikonomia functioning in the ordered arrangement of the household, the economic theologians transposed this concept into the theological field in which it acquired the meaning of a divine plan of salvation (Agamben 2011).

The theological problem how to reconcile the unicity of God with the Trinity can now be solved: As the being of God is concerned, he is absolute one, but as the actions of God are concerned and the way he manages the world, he is three. More important for our discussion in this article is that although the economic theological paradigm is in first instance non-political, following Aristotle's strict distinction between economics and politics, the economic notion of divine providence and management of the world is transposed to the political governance of men. The theological distinctions between the being of God (sovereignty) and the actions of God (oikonomia) were transposed to the governance of men, i.e., kingdom as sovereign nonexecutive power (auctoritas) and administration and management as executive power (potestas) (Agamben 2011).

If we apply Agamben's categories in the contemporary context of governance practices, we recognize the distinctions he traced in the intellectual history of the West. ${ }^{6}$ The idea that 'the King reigns but doesn't govern' is for instance transposed from the theological domain to the domain of political governance of men, and can be recognized in contemporary monarchies where the sovereign power of the king reigns without having any executive power. And in corporate governance of publicly listed companies for instance, we recognize this distinction in the separation between the executive board and the non-executive board. In other words, Agamben's conceptualization of the economic theological paradigm of governance next to the political theological paradigm explains common dichotomies in political life - kingdom and government, being and action, auctoritas and potestas, ordinatio and executio, law and order etc. - and explains the genealogy of economic governance in contemporary liberal democracies in the West, as well as the present domination of economy and management over all aspects of social life (cf. Salzani 2012; Whyte 2013).

We now return to Agamben's reading of the genealogy of governance to further clarify the relation between economic and political governance. By tracing the theological origins of our notion of governance, Agamben not only explains why contemporary governance has taken the form of economic governance - theology conceives divine life as oikonomia (providence as divine government of the world) - which is transposed to the government of men. It also explains why governance always has these two aspects associated with being and action which cannot be reduced to each other - kingdom concerns the ontological level of the being of God while government concerns the practical level of the actions of God - while they also cannot be

\footnotetext{
${ }^{5}$ In fact, Agamben is ambiguous in this. Sometimes he suggests that economic governance can exist independently because it is not dependent on sovereign power (Agamben 2011; 17-18) - it is an-archic - while he at the same time argues that governance is dependent on such sovereign power (Agamben 2011: 5) as we will see in the next section. If we take the idea of governance as bi-polar machine of sovereign political and economic power serious, we have to acknowledge their mutual dependency. This implies that they always co-exist and cannot exist independently.

${ }^{6}$ It is clear that Agamben himself didn't apply his categories in the context of contemporary governance practices. If we pursue this way in this article, we depart from a strict interpretation of his work and apply his categories for our own purposes.
} 
completely separated - as the son of God, Jesus cannot be 'lower' than God and is godlike himself. The being of God concerns the sovereign transcendent power to establish normative principles according to which reality appears as established order, and the actions of God concern the economic administrative power to manage this established order in light of these normative principles (Agamben 2011: 81). In profane governance of life on Earth, we can recognize this inseparability of both types of governance according to Agamben; a governance structure that is only characterized by sovereign power would be ineffective and impotent, while a governance structure which is only characterized by economic power would be groundless and anarchic (Agamben 2007). Therefore, both aspects constitute governance as 'bipolar machine' according to Agamben, i.e., of sovereign or legislative power through universal laws, principles and norms, and of economic or executive and managerial power that applies these laws and principles in practice. $^{7}$

If we apply Agamben's concept of governance as bipolar machine in the context of our discussion of the duality of governance that we introduced in the previous section, it can help us to reflect on the relation between political and economic governance. If we see a dominance of economy over politics as a result of deregulation, privatization and marketization, i.e., an economic sovereignty of the market instead of a political sovereignty over the market economy, than Agamben's categories can help us to diagnose the current situation. On the one hand, his categories help us to conclude that the current dominance of economics over politics testifies of an economic type of governance that is not limited by sovereign principles but is an-archic, a political 'empty' type of governance which can be associated with limitless capitalism (cf. Whyte 2013). On the other hand, his categories can help us to understand that the dominance of economics over politics doesn't imply an 'end of politics' and ultimate victory of capitalism, but that it is embedded in the historical tension between sovereignty and oikonomia which constitutes this bipolar machine of governance. Based on this reading of Agamben's genealogy of governance, we then could argue for the rehabilitation of sovereign or political power in order to limit the economic governance associated with capitalism.

And yet, such a rehabilitation of political power would miss however a more fundamental problem that Agamben has with the classical notion of sovereign governance as politicallegislative power to establish universal rules, norms and principles. Agamben argues that such an establishment of governance by sovereign power involves a 'state of exception' (Agamben 2005). We turn now briefly to Agamben's notion of the state of exception in order to deepen our understanding of the concept of sovereign governance.

In political life, the sovereign can always decide on the exception or take an extra-legal decision, for instance in case of a crisis. In such a crisis, the sovereign can decide to temporarily suspend the applicability of the law or, in case of a revolution, to suspend the old law and replace it by a new law based on an extra-legal decision (Humphreys 2006). Based on many examples in legal history, Agamben shows that such a state of exception is exceptional in history, but increasingly becomes the "paradigm of government" in the West (Agamben 2005: 7). For Agamben, the philosophical significance of the state of exception consists in the acknowledgement that a law, norm or principle functions as an inclusion and exclusion criterion. A classic example is the foundation of the Greek democratic political

\footnotetext{
${ }^{7}$ To the extent that oikonomia concerns the origin of economy according to Agamben's genealogy of economy and government, as the subtile of The Kingdom and the Glory suggests, we are legitimized to conceptualize oikonomia as economy and management. This is also confirmed in Agamben's interviews in which he directly connects his understanding of oikonomia with economic management (Agamben 2007).
} 
system, which consisted in the suspension of the old law and the introduction of a new law that in fact includes free men in the political-legislative system and excludes women and slaves. With this, it becomes clear that any law or principle acknowledges the law's outside - the law that defines what is free man implies at the same time the existence of behaviour that falls outside this definition. Women and slaves as such 'outlaws' drive the constitution of the legal system and the execution of extensive power to integrate them within the system - whether by punishment and sanctions or by education and cultural assimilation - and at the same time, the remaining 'outlaws' are reduced to 'bare life' of an a-political existence. ${ }^{8}$

If we apply Agamben's notion of the state of exception of sovereign governance in the context of CSR, we easily see what is at stake. One of the domains of CSR is corporate sustainability in order to address the global challenge of global warming. If global warming is framed as an urgent global problem and threat of humanity, as is indicated in many books and reports, and if a 'rhetoric-reality' gap exists between political statements about the climate actions needed and the lack of corporate responsible action in practice, one can question the ability of economic institutions to take corporate responsibility to address this global problem and call for political action (see §1). But one can question whether the current democratic institutions are able to actually address the problem (Flinders and Wood 2014). Not only do we not have a systematic politics of climate change (Giddens 2011), but we can even question whether climate action can be made in liberal democratic societies because of the self-interest of the powerful elites and/or the relatively short time horizon of democratic policy makers (cf. Shearman and Smith 2007; cf. Flinders and Wood 2014). This emergency of the problem in combination with political inaction may call for a state of exception, i.e. authoritative interventions by the state. A country like the US could for instance install a system of global climate controlling satellites, while using undemocratic procedures (cf. Oels 2012). With this sovereign political intervention, a law defines what is sustainable performance (e.g. integration of both economic and environmental sustainability for instance) and what falls outside this law (e.g. environmental unsustainable behaviour performed by companies that are solely focussed on economical sustainability). These companies, that can be seen as 'outlaws', drive the constitution of the legal system and the execution of extensive power to integrate them within the system. The call for an 'authoritarian regime' to politicize the climate change challenges (Shearman and Smith 2007) testifies of such a sovereign attempt to capture and control this anomy by bringing this 'outside' of the law under the jurisdiction of the law.

\footnotetext{
${ }^{8}$ While Agamben associates the state of exception with sovereign power in his early work, in The Kingdom and the Glory, he seems to associate it with economic power as well. "The paradigm of government and of the state of exception coincide in the idea of an oikonomia, an administrative praxis that governs the course of things, adapting at each turn, in its salvific intent, to the nature of the concrete situation against which it has to measure itself' (Agamben 2011: 50). This doesn't mean that both coincide. While the state of exception is clearly related to universal rules and norms that imply inclusion and exclusion practices, as Agamben has shown convincingly, this cannot be said of economic governance. Oikonomia concerns the administrative action which can be performed without a set of rules or principles, as is the result of situational and pragmatic consideration on a case to case basis (cf. Whyte 2013). According to Aristotle, economy concerns the administration of the household with respect to the satisfaction of needs. The political domain of living the good life limits economy and thanks to this limitation, a rational or virtuous economy is possible which doesn't degenerate. Without such a limitation by politics, economy would degenerate and end in the limitless accumulation of wealth. Agamben points in another direction. Even if economy is limited by the political domain, it doesn't result in the good life because of the state of exception it is dependent upon. While sovereign power neglects the singularity of human existence in favour of the generality of rules and principles, economic power can be seen as the actual disciplining power which is at stake in the economic execution of inclusion and exclusion practices. In this respect, we can also speak of an economics of exception.
} 
Although the current institutional inadequacy to tackle global warming (Gardiner 2006) may provide arguments for the installation of such an authoritarian climate politics, Agamben's categories show that such a state of exception, which is inherent in sovereign power, would reduce the individual responsibility of corporate actors - the sustainable entrepreneur or responsible manager - in light of the totalitarian claims by the universal laws, rules or principles. ${ }^{9}$

If we apply Agamben's concept of the state of exception of governance in the context of corporate governance, we recognize these inclusion and exclusion mechanisms as well. Companies nowadays form multi-stakeholder alliances and cross-sector partnerships together with research institutes and NGO's in order to address complex societal issues. The governance of these partnerships is difficult because of the different value frames and roles of the actors and the power relations involved. In the literature, various governance interventions are proposed to deal with these issues, such as value frame fusion (Le Ber and Branzei 2010) or constructive conflict (Cuppen 2012). As we have indicated elsewhere, most literature on governance arrangements have the tendency to harmony, consensus and alignment among multiple stakeholders (Blok 2014), while fundamental differences among these stakeholder are insufficiently taken into account. Based on Agamben's work, we could explain this tendency to harmony and consensus as the result of the state of exception, i.e. of the introduction of a norm or principle for inclusion and exclusion, in which the fundamental differences among stakeholders are neglected in favour of their commonality (Blok 2018a). The state of exception in corporate governance practices is further confirmed by inclusion and exclusion tactics in the framing of the problem and in the selection tactics of stakeholders and partners for collaboration; radical stakeholder groups are often excluded from the collaboration while modest stakeholders are included (Blok 2014).

Also at the organizational level, the state of exception can be found in corporate governance practices. Corporate governance introduces general procedures and norms, which show what is seen as important for a company, for instance profit and sales, but also social and environmental aspects. The state of exception is found in the disciplinary power of corporate governance initiatives in which the singularity of the individual employee or manager and his or her value frames and norms are neglected in favour of common corporate goals. Standardisation for instance makes comparability possible, but implies the neglectance of the singularity of individual managers and employees (Robert 2001).

Because the state of exception is inherently involved in governance practices, we can understand why the criticism of the current dominance of economic governance over political sovereignty - which can be associated with the inability of market economies to perform ethically in business life - cannot simply be solved by calling for the rehabilitation of sovereign or politic power in order to limit economic governance. In such a situation, we may seem to engage in social responsibility by political interventions, but we subscribe consciously or unconsciously to the state of exception as well, in which the individual responsibility of

\footnotetext{
${ }^{9}$ Contrary to the state of exception of sovereign governance, which founds a politics of inclusion and exclusion, Agamben proposes to develop a notion of politics beyond sovereign law and based on his notion of bare life. For Agamben, the reduction of the singularity of human existence to bare life in light of totalitarian claims by universal laws shows a non-relation between law and life and opens a new perspective on politics. While politics is always seen within the context of the law - whether it is constitutive power that establishes the law or is contaminated by the law - Agamben explores the possibility to move beyond the connection of politics and law and to connect it with bare life in his project (Agamben 2005: 88; Humphreys 2006: 683-684). The further elaboration of this notion of politics is beyond the scope of this article.
} 
corporate actors - the sustainable entrepreneur or responsible manager - is neglected. This raises the question how we can govern CSR without neglecting the individual responsibility of the actors involved (see further next section).

With the help of Agamben's conceptuality and our application of his categories in the context of corporate governance in this section, we can now re-reconsider the sovereignty of the market that we discussed in the previous section. Based on Agamben's conceptuality of the bipolar machine of governance, we can first of all argue that the diagnosis of a sovereignty of the market is wrongly stated because there is no such thing. Sovereignty concerns the ontological level of universal rules, principles and norms, and we have seen that economy concerns the practical level of administration and management. So if we want to frame the diagnosis, we have to frame it as an age of economic governance without sovereignty. From the perspective of Aristotle, economic thinking which is not limited by the political ideals of the good life is not economic in the proper sense of the word, but a limitless accumulation of wealth. This is called chrematistics. Interestingly enough, chrematistics is pretty much comparable with what we nowadays see as the liberal market economy.

Second, however, based on Agamben's conceptuality, we could argue against such a diagnosis of an economic governance without sovereignty today: "Today, we could say that the act of government or execution has the primacy, it is clear, the crisis of parliamentary and legislative power is evident everywhere. It is like dead, legislative power doesn't exist anymore in Europe or the United States, an absolute primacy of government. But anyway even in this case - both poles are there: so one pole can prevail on the other, like now it is the case for government and executive power, but nevertheless they must be there, otherwise no government, there is another form of power" (Agamben 2007: 5). Why? If we take the idea of governance as bi-polar machine serious, we have to reject the idea of an economic governance without sovereignty. Also in the current hegemony of economic governance, the role of sovereign power is still important. This is confirmed by the current practice of deregulation and marketization that goes hand in hand with the enlargement of the whole legal system (Sustainable Development Goals, Carbon pricing systems etc.). Economic and sovereign power in fact go together and build this bi-polar machine.

Third, based on Agamben's conceptuality, we could criticize a strict distinction between sovereignty and economic governance today. A strict differentiation between economic and political institutions is merely apparent because all actors are political/economic from this perspective, are determined by this bi-polar machine. ${ }^{10}$ The marketization of global warming in the bio-based economy and the politization of corporate activities, ranging from lobbying activities to political CSR for sustainability, can illustrate these trends. This corresponds with the idea that regulation in the network society cannot be seen any longer as state intervention, but as part of a political-economic constellation of power in which political and economic

\footnotetext{
${ }^{10}$ Agamben's criticism of a strict distinction between political and economic governance makes clear that the 'state' of exception can be considered as 'economics' of exception as well. In this respect, he anticipated criticisms like the one uttered by Hardt and Negri: "The political is not an autonomous domain but one completely immersed in economic and legal structures" (Hardt and Negri 2009: 5). For Agamben, the state of exception is connected with governance as bi-polar machine of both sovereignty and economic governance. It may be the case that Agamben, because he associates the state of exception both with political and economic governance, doesn't pay full attention to other problems which can be associated with economic governance. Although Negri and Hardt misunderstood Agamben, as if he associated the state of exception only with sovereign governance, they hint in this direction when they say that by focussing on the sovereign exception, "economic and legal structures of power tend to be pushed back into the shadows" (Hardt and Negri 2009: 4).
} 
actors are intertwined and mutually dependent. It is clear that the call for a bio-based or circular economy for instance is not merely political or economic. This calls the whole dichotomy between sovereignty of the market versus sovereignty over the market into question and calls for the acknowledgement that politics and economics do no longer represent two separate domains where one of the two is sovereign over the other. It rather shows that economic institutions are always already political and economic; always involve already political and moral statements about what is good and wrong, what for instance are good relations of business and society, good ways of production, distribution and customer relationships etc. Examples are the free market as a norm in either economic and political life, or the sole economic role of economic actors in society as a principle.

Our analysis in this section shows that in a fundamental way, the question about the political legitimation of corporate governance, whether it is found in political CSR within economic institutions or in political limitations of economic institutions, always comes too late. Corporate governance is always already guided by a bi-polar machine of governance, whether this is found in 'internal' corporate sovereignty (mission statements and core values for instance that guide CSR policies or in 'external' political sovereignty (governmental rules and regulations that enhance and secure corporate responsible behaviour). We could argue that sovereign governance and economic governance have to be understood as di-polarities where no clear line can be drawn between political and economic actors as if they were two different substances. In fact, the continuous oscillation between political and economic tendencies constitutes a field in which both rely on each other and are in continuous tension (cf. Raulff and Agamben 2004; Whyte 2013; Agamben 2011). For this reason, we will no longer talk about either economic or political actors in this article, but about economic/political actors.

Based on Agamben's conceptuality of governance as bipolar machine, we can criticize the current discourse about the sovereignty of the market and call for a new sovereignty over the market, because it shows that control cannot be found in a unilateral preference of political sovereignty over economic governance or vice versa. In fact, the symmetry between sovereignty and economy in governance as bi-polar machine shows why economic governance may pretend not to make use of norms, but requires such norms on the one hand, and in fact implicitly presupposes such norms in a self-evident and uncritical manner. The concept of governance as bipolar machine in fact provides good reasons for our acceptance of the bipolar machine of sovereignty and economics in which both approaches are integrated in a governance framework for CSR and reflection on the presupposed principles and norms is an integral part of the effort to perform ethically in business life. What is more, governance as bipolar machine can also help to criticize the current calls for a new sovereignty over the market, because they may unconsciously subscribe to the state of exception in which the individual responsibility of corporate actors and their viewpoints is neglected and disciplined in favour of 'common' goals.

In sum, although Agamben's genealogy of the concept of governance helps us to analyse current practices of governance, his main contribution is that his conceptuality enables us to take a critical stance. The problem is therefore not that politics should be rehabilitated because such a rehabilitation wouldn't deal with the real problem at stake, namely that each governance framework is characterized by the state of exception. The question then is not how economic actors can be limited by political action, but whether the politics of economic institutions, whether it is found in political CSR or in the political limitation of economic institutions by political institutions, can ever be seen as a suitable governance model. 


\section{Philosophical Reflections on the Concept of Corporate Governance}

At the same time, we may argue that something radically changed in our current society, which is threatened by global warming. On the one hand, CSR can be seen as a corporate approach to integrate grand challenges like global warming in business operations (Dahlsrud 2008). On the other hand, the urgency of this challenge requires that immediate action is taken by actors in society, including economic institutions. The current political, in which inaction is made excusable because of the complexity of the problem (the difficulty of global politics, scientific uncertainty about calculations of future climate impacts etc.), and which facilitates the delay of actual climate action at our convenience, is no longer possible (Gardiner 2006). On the contrary, we need all the creativity and innovative potential to come up with new solutions of global warming, like geo-engineering etc. Does this mean that we have to rehabilitate the bipolar machine of governance as sovereign power and economic management by economic institutions?

We can argue against such a rehabilitation if we take the nature of grand challenges like global warming serious. We have to acknowledge that there is no sovereignty, no general principle, norm or law that can guide us in the solution of these challenges. While the performance of corporate responsible behaviour presupposes that we know what is right and wrong in business life, grand challenges like global warming can be considered as highly complex or 'wicked' problems (cf. Rittel and Webber 1973). Wicked problems are complex, ill-structured and public problems, like life-style diseases, poverty in the South and climate change. Several authors have indicated that global warming is such a highly complex problem because it concerns global and interconnected issues like climate change, increasing populations and changing consumption patterns, which cannot be solved in traditional ways or by simple solutions (Blok et al. 2016; Brennan 2004; Ehrlich and Ehrlich 2009)). Further indications of this wickedness can be found in the dispersion of causes and effects emissions of greenhouse gasses (GHG) are produced in a particular geographical area but have global effects - in the fragmentation of agency - there is no centralised system of global governance to tackle this global problem, while local agents have the tendency to serve their own (unsustainable) interests (cf. Harding 1968) - and in institutional inadequacy - local enforceable sanctions to enhance and secure more sustainable behaviour is limited by the current, mainly national institutional context (Gardiner 2006; cf. Jamieson 2007). In such a context, it is difficult, if not impossible, to conceptualize how different human stakeholder groups and institutions, who have a broad variety of perspectives and interests, accept responsibility "to maintain a non-declining set of opportunities based on possible uses of the environment for future members of their communities" (Norton 2000: 1043).

If the key characteristic of grand challenges like global warming is that the distinction between good and bad behaviour is difficult because of their complexity, it is impossible to identify sovereign laws, norms or principles that can help us to unequivocally distinguish good from bad behaviour regarding these type of challenges. This is the fundamental problem of the call for an authoritative regime of global warming, because such a regime presupposes that appropriate norms and principles can be identified, while this is highly questionable if we acknowledge the wickedness of global warming. For instance, it only makes sense to introduce an authoritative regime if we know which behaviour is appropriate, and especially in case of wicked problems like global warming, we don't know which behaviour is appropriate. We 
have no familiarity with future generations that live on Earth in about 1000 years, we don't know their values and stakes or anything else that can guide our current behaviour. In other words, if we take our epistemic insufficiency regarding the future impacts of our current interventions serious, we don't know which norm or principle could guide our politics of climate change. Not only political government is limited in case of grand challenges, but also economic governance. Economic management and control practices are dependent on sovereign principles and norms, while precisely these norms fail in the case of grand challenges which involve a variety of ideas and values frames of different stakeholders. So even if we want to rehabilitate the bipolar machine of governance because of the urgency of global warming, we have to acknowledge our epistemic insufficiency with regard to both the proper norms and principles (sovereign governance) and the proper management of the problems based on these norms (economic governance). How to navigate between the extremes of a call for an authoritative politics of climate change, which remains groundless in light of the wickedness of global warming, and a political inactivity that is certainly convenient for companies in the Northern hemisphere, but definitely catastrophic for future generations and people in the global South.

Instead of engaging in a pragmatic strategy to tackle these grand challenges in business life (Ferraro et al. 2015), we engage in a philosophical reflection on the grand challenge of global warming in this article, and ask whether such global problems leave room for a state of exception. If we reflect on the global character of the environmental crisis we face today, we understand that a fundamental state of inclusion in this problem situation is at stake. The experience of global warming primarily concerns the experience of the globe as a whole. Or put in more philosophical terms, the experience of the whole of being, in which the one who experiences is included (Zwier and Blok 2017). While in previous times, we may thought that we could externalize waste and emissions to the environment, we currently experience that all waste and emissions we try to externalize return to us as a boomerang, namely in terms of global warming which is therefore inescapable for us. With this, the Earth becomes an interior space in which we are included, i.e. without any possibility of a position outside this whole. It provides an experience of the immanence of human existence and its institutions to the world we live in and on which we entirely depend. This opens a new perspective on the state of exception, which is characteristic for current climate governance; the state of exception of climate governance turns out to be embedded in a fundamental state of inclusion in this problem. So even if we acknowledge that governance is characterized by a state of exception, we may argue that such an exception is embedded in a state of inclusion. What is at stake in wicked problems like global warming is an intimacy of actors in the interior space of planet Earth.

A more proper orientation for climate governance by economic-political actors emerges if we ask: what is it, in which we are included? We can argue that planet Earth itself could function as sovereign principle or norm that should guide our climate governance. On the one hand, we can identify the Earth as sovereign principle for our existence, to the extent that human existence emerges, unfolds and expands based on the pre-existence of the Earth, and threatens to go back into the Earth at the end of this era in which humanity is threatened by global warming (cf. Blok 2016). The Earth can be seen as sovereign in the literal sense of the word. It is the highest (or better, lowest), whose height itself is no longer dependent on or relative to something else: it concerns the absolute (cf. Nancy 2007). The unique situation of planet Earth that is threatened by global warming unsettles us - we experience our full 
dependency on the carrying capacity of the Earth for the first time - and calls us to sustain this Earth as supportive ground for human existence. ${ }^{11}$ This call is normative, since the Earth as supportive ground operates as norm or regulative idea that guides behaviour. This norm is 'open' for revision, as opposed to general or universally valid, to the extent that the application of this norm remains always a finite or limited one compared to the wickedness of the problem, remains always questionable, adjustable and improvable. This means that any norm always remains situational - only valid in a limited way and for a specific purpose and time frame, while we have to remain principally critical towards the applicability of such a norm or principle in light of this wickedness of the problem at stake. Such an 'open' norm precludes every effort to establish an authoritative regime, while it at the same time prevents political inaction.

Corporate governance of economic/political actors is guided by this open norm as well; corporate governance actually engages in corporate responsible behaviour to address grand challenges like global warming, while it acknowledges the situational character of all governance interventions. It provides a concept of corporate governance that doesn't claim any universal or general validity of its interventions because of the epistemic insufficiency of economic/political actors regarding the wickedness of problems like global warming.

Based on these considerations, we propose a bipolar concept of corporate governance as administration of planet Earth, in which planet Earth itself operates as sovereign dimension for corporate governance of the Earth by economic/political actors. This notion of corporate governance acknowledges the ultimate dependency of economic/political actors on the biophysical capacities and limitations of planet Earth. We develop four preliminary characteristics of this notion of corporate governance that can help economic/political actors to navigate between an authoritarian politics of global warming and political inactivity.

1) If corporate governance concerns the Earth as a whole, and this whole constitutes an interior space in which any state of exception is embedded, then corporate governance is characterized by a state of inclusion. Contrary to any ex-ceptional position, economic/ political actors are radically involved in the governance of this interior space. This state of inclusion does not only highlight their dependency on the Earth as supportive ground for their public and private operations, but also their responsibility when it comes to sustaining the Earth as such a supportive ground. Contrary to the state of exception that favours the generality and universality of norms and principles over the singularity of actors, the state of inclusion highlight the individual responsibility of economic/political actors as intimately connected with this interior space in corporate governance. ${ }^{12}$ Corporate governance involves a shift from a governance style based on normative rules and principles a being held responsible for global warming based on general norms and principles - to a governance style based on the singular normativity of the Earth - taking responsibility for global warming in actual corporate responsible action and behaviour (Blok et al. 2016)

\footnotetext{
${ }^{11}$ With this, we do not want to imply yet that the Earth has a call on human existence to act in an ethical way, as is sometimes suggested in the literature (Blok 2015). We leave this question aside for the moment and highlight the normative dimension of the Earth, whether this Earth positively or negatively calls for our taking actual responsibility in our actions and behaviour.

12 With this intimacy, we don't have a complete coalescence of man and Earth in mind in which no-self is left, but an intimacy which acknowledges the res-cendence of the spacio-temporal infinity of the Earth beyond our human involvement, an asymmetric relation between man and Earth at the same time. The articulation of this intimate asymmetry is beyond the scope of this article.
} 
through which the Earth as oikos for human existence and its institutions subsists. As a consequence, corporate governance is characterised by the situational and fundamentally limited character all interventions in light of the epistemic insufficiency of economic/ political actors with regard to global challenges like climate change.

2) This type of corporate governance is not only conditioned by the singularity of each and every actor involved, as if it consists in economic governance without any sovereignty. This would suggest that the governance of planet Earth as oikos of human existence is primarily in the hands of human management and control to provide for the needs of human life. But in fact, also human efforts to manage and control the Earth are always already dependent on the Earth as supportive ground. In this sense, corporate governance is always already Earthbound, i.e. primarily conditioned by grand challenges like global warming that unsettle actors and call them to sustain the planet, here and now, in order to subsist as dimension beyond our human control. Corporate governance is responsive to the normative dimension of planet Earth that operates as a regulative idea or 'open' norm, without being able to derive general rules or principles that can be univocally applied in governance practices.

3) Because of the situational character of corporate governance (characteristic 1) in response to the normative dimension of planet Earth (characteristic 2), corporate governance acknowledges the principal fallibility of our interventions in light of our epistemic insufficiency with regard to this normative dimension. It is this fallibility of governance - the negativity, struggle and difficulties inherent in governance - that was already conceived by theologians of the Middle Ages (Mondzain 2007). This fallibility is not only due to the situational character of corporate governance, but may also be due to the instability and volatility of planet Earth itself, as is indicated in the structural possibility of earthquakes, volcano's and tsunami's.

4) At the same time, since grand challenges like global warming can be seen as urgent problems, corporate governance cannot consist in any form of quietism but calls for action, involves actual action and behaviour in response to the normative dimension of planet Earth, and consists in the development of responsible patterns of production and consumption. CSR can be seen as acclamation or corporate laudation of this normative dimension of planet Earth by the actual execution of corporate responsible action and behaviour, in which the Earth functions as normative principle that enforces ethical behaviour in business life. In the acclamation of the normative dimension of planet Earth, social responsible action and behaviour of economic institutions is glorified (cf. Agamben 2007). Because of the fallibility of any norm or principle, corporate governance does no longer look for perfect solutions to global challenges like climate change, but for satisficing solutions that are, first of all, satisfactory and sufficient to maintain planet Earth as supportive ground for human existence and its institutions and, secondly, are radically open to future subversions, revisions and improvements (cf. Blok 2018b). Political/ economic actors feel responsible for corporate governance and engage in the exploration and exploitation of such satisficing solutions, but acknowledge their epistemic insufficiency with regard to the super wicked problem of global warming at the same time.

\section{Conclusion}

In this article, we philosophically reflected on the nature of governance in order to develop a concept of corporate governance that enhances and secures firm's commitment to CSR. Our critical engagement with economic and political responses to the call for more CSR in section 
one and with Agamben's analysis of the relation of economics and politics in economic/ political actors in section two, enabled us to argue for a concept of governance of economic/ political institutions which is characterized by a state of inclusion, rather than a state of exception. We subsequently developed four characteristics of corporate governance which seem to align with broader economic frameworks, ranging from the steady-state economy (Daly 1991) to the Doughnut economy (Raworth 2017). The four characteristics of corporate goverance can guide political/economic actors to actually engage in corporate responsible action and reform, thereby moving beyond the extremes of the current economic and political responses to the call for more CSR. It remains open for future research to assess whether this concept of corporate governance is better able to deal with the often chaotic debates about grand challenges like global warming, in which many different viewpoints and value frames compete for attention.

\section{Compliance with Ethical Standards}

Research Ethics Statement This paper is a conceptual paper and doesn't involve empirical material. I ensure quality and integrity of my research.

Conflict of Interest This paper is a conceptual paper and no conflicts of interest are involved.

Open Access This article is distributed under the terms of the Creative Commons Attribution 4.0 International License (http://creativecommons.org/licenses/by/4.0/), which permits unrestricted use, distribution, and reproduction in any medium, provided you give appropriate credit to the original author(s) and the source, provide a link to the Creative Commons license, and indicate if changes were made.

\section{References}

Abor, J., and C.K. Adjasi. 2007. Corporate governance and the small and medium enterprises sector: Theory and implications. Corporate Governance 7 (2): 111-122.

Agamben, G. 1998. Homo Sacer: Sovereign power and bare life. Stanford: Stanford University Press.

Agamben, G. 2005. State of exception. Chicago: University of Chicago Press.

Agamben, G. (2007). The power and the Glory: Giorgio Agamben on Economic Theology, transcript of a presentation in Turino on January 11, 2007 (accessible via: http://www.pubtheo.com/page.asp?pid=1566].

Agamben, G. 2009. What is an apparatus. Stanford UP: Stanford.

Agamben, G. 2011. The kingdom and the glory. Stanford UP: Stanford.

Aguinis, H., and A. Glavas. 2012. What we know and Don't know about corporate social responsibility: A review and research agenda. Journal of Management 38 (4): 932-968.

Andersen, M., and T. Skjoett-Larsen. 2009. Corporate social responsibility in global supply chains. Supply Chain Management 14 (2): 75-86.

Aristotle. 1944. Politics. Cambridge: Harvard UP.

Assländer, M.S., and J. Curbach. 2017. Corporate or governmental duties? Corporate citizenship from a governmental perspective. Business \& Society 56 (4): 617-645.

Bakan, J. 2005. The corporation: The pathological pursuit of profit and power. New York: Free Press.

Bauman, Z. 2002. Liquid modernity. Cambridge: Polity.

Blok, V. 2014. The metaphysics of collaboration: Identity, unity and difference in cross-sector partnerships for sustainable development. Philosophy of Management 13 (2): 33-52.

Blok, V. 2015. The human glanze, the experience of environmental distress and the 'affordance' of nature: Toward a phenomenology of the ecological crisis. Journal o Agricultural and Environmental Ethics 28 (5): 925-938.

Blok, V. 2016. Thinking the earth after Heidegger: Critical reflections on Meillassoux's and Heidegger's concept of the earth. Environmental Ethics 38 (4): 441-462. 
Blok, V. 2017. Bridging the gap between individual and corporate responsible behaviour: Toward a performative concept of corporate codes. Philosophy of Management. https://doi.org/10.1007/s40926-016-0045-7.

Blok, V. 2018a. From participation to interruption: Toward an ethics of stakeholder engagement, Participation and Partnership in CSR and Responsible Innovation". R. von Schomberg \& J. Hankins (Eds.), Handbook Responsible Innovation: A Global Resource. (Edward Elgar 2018 forthcoming).

Blok, V. 2018b. Information asymmetries and the paradox of sustainable business models: Towards an integrated theory of sustainable entrepreneurship. In Sustainable business models: Principles, promise, practice, ed. L. Moratis, F. Melissen, and S. Idowu, 203-226. Dordrecht: Springer.

Blok, V. (2019) Xenophon's philosophy of management. Handbook of Philosophy of Management. Dordrecht: Springer (forthcoming).

Blok, V., B. Gremmen, and R. Wesselink. 2016. Dealing with the wicked problem of sustainable development. The role of individual virtuous competence. Business and Professional Ethics Journal 34 (3): 297-327.

Brennan, A. 2004. Biodiversity and agricuoltural landscapes: Can the wicked prolicy problem be solved? Pacific Conservation Biology 10 (2): 124-142.

Castells, M. 2000. The rise of the network society. Chichester: Wiley.

Cuppen, E. 2012. Diversity and constructive conflict in stakeholder dialogue: Considerations for design and methods. Policy Sciences 45: 23-46.

Dahlsrud, A. 2008. How corporate social responsiility is defined: An analysis of 37 definitions. Corporate Social Responsibility and Environmental Management 15: 1-13.

Daly, H.E. 1991. Steady-state economics. 2nd ed. Washington: Island Press.

de la Durantaye, L. 2009. Giorgio Agamben: A critical introduction. Stanford: Stanford University Press.

DeMartino, G.F. 2011. The economist's oath. Oxford: Oxford University Press.

Deslandes, G. 2018. Weak theology and organization studies. Organization Studies: 1-18.

Ehrlich, P.R., and A.H. Ehrlich. 2009. The Populatioon bomb revisited. Electronic Journal of Sustainable Development 1: 63-71.

European Commission. (2010). Green paper: Corporate governance in financial institutions and remuneration policies (Bruxelles).

Ferraro, F., D. Etzion, and J. Gehman. 2015. Tackling grand challenges pragmatically: Robust action revisited. Organization Studies 36 (3): 363-390.

Filatotchev, I., S. Torns, and M. Wright. 2006. The firm's strategic dynamics and corporate governance life-cycle. International Journal of Managerial Finance 2 (4): 256-279.

Flinders, M., and M. Wood. 2014. Introduction special issue Depoliticisation, governance and the state. Policy \& Politics 42 (2): 135-149.

Gardiner, S.M. 2006. A perfect moral storm: Climate change, intergenerational ethics and the problem of moral corruption. Environmental Values 15 (3): 397-413

Giddens, A. 2011. The politics of climate change. 2nd ed. Cambridge: Polity.

Gond, J.P., N. Kang, and J. Moon. 2011. The government of self-regulation: On the comparative dynamics of corporate social responsibility. Economy and Society 40 (4): 640-671.

Haines, F. 2011. The paradox of regulation. What regulation can achieve and what it cannot. Cheltenham: Edward Elgar.

Harding, G. 1968. The tragedy of the commons. Science 162: 1243-1248.

Hardt, M., and A. Negri. 2009. Common wealth. Cambridge: Belknap Press.

Hens, I., and B. Nath. 2003. The Johannesburg conference. Environment, Development and Sustainability 5 (2003): 7-39.

Humphreys, S. 2006. Legalizing lawlessness: On Giorgio Agamben's state of exception. The European Journal of International Law 17 (3): 677-687.

Idowu, S.O. 2010. Professionals' perspectives of CSR: An introduction. In Professionals' perspectives of corporate social responsibility, ed. S.O. Idowu and W. Leal Filho, 1-8. Dordrecht: Springer.

IPPC AR-5 (2014) Climate Change 2014. Synthesis Report. IPCC: Geneva.

Jamieson, D. 2002. Morality's progress: Essays on humans, other animals, and the rest of nature. Oxford: Clarendon Press.

Jamieson, D. 2007. The moral and political challenges of climate change. In Creating a climate for change, ed. S.C. Moser and L. Dilling, 475-482. Cambridge: Cambridge University Press.

Jones, M.T. 2009. Disrobing the emperor: Mainstream CSR research and corporate hegemony. Management of Environmental Quality: An International Journal 20 (3): 335-346.

Kallio, T.J. 2007. Taboos in corporate social responsibility discourse. Journal of Business Ethics 74 (2): $165-175$ Authors.

Le Ber, M.J., and O. Branzei. 2010. Value frame fusion in cross sector interactions. Journal of Business Ethics 94: $163-195$.

Majone, G. 1994. Paradoxes of privatization and deregulation. Journal of European Public Policy 1 (1): 53-69. 
Mamic, I. 2005. Managing global supply chain: The sports footwear, appare and retail sectors. Journal of Business Ethics 59 (1): 81-100.

Melewar, T., C., Karaosmanoglu. E. 2006. Seven dimensions of corporate identity: A categorisation from the practitioner's perspective. European Journal of Marketing 40(7/8): 846-869).

Midttun, A. 2005. Realigning business, government and civil society. Corporate Governance 5 (3): 159-174.

Mondzain, M.J. 2007. Image, icon, economy: The byzantine origins of the contemporary imaginary. Stanford: Stanford UP.

Moon, J. 2002. The social responsibility of business and new governance. Government and Opposition 37: 385-408.

Nancy, J.L. 2007. The creation of the world or globalization. New York: Suny.

Norton, B.G. 2000. Biodiversity and environmental values: In search of a universal earth ethic. Biodiversity and Conservation 9: 1029-1044.

Oels, A. 2012. Fron 'securitization' of climate change to 'climatization' of the security field: Comparing three theoretical perspectices. In Climate change, human security and violent conflict, ed. J. Scheffran, M. Brzoska, H.G. Brauch, P.M. Link, and J. Schilling. Dordrecht: Springer.

Raulff, U., and G. Agamben. 2004. An interview with Giorgio Agamben. German Law Journal 5 (5): 609-614.

Raworth, K. 2017. Doughnut economics: Seven ways to think like a $21^{\text {st }}$ century economist. London: Chelsea Green Publishing.

Rittel, H.W.J., and M.M. Webber. 1973. Dilemmas in a general theory of planning. Policy Sciences 4 (2): 155-169.

Robert, J. 2001. Corporate governance and the ethics of narcissus. Business Ethics Quarterly 11 (1): $109-127$.

Roelofsen, M., V. Blok, and E. Wubben. 2015. Maintaining the CSR-identity of sustainable entrepreneurial firms. The role of corporate governance in periods of business growth. In Corporate social responsibility and governance. Theory and practice, ed. S.O. Idowu, C.S. Frederiksen, A.Y. Mermod, and M.E.J. Nielsen, 6388. Dordrecht: Springer.

Salzani, C. 2012. "The kingdom and the glory", book review. Journal of Contemporary European Studies 20 (2): $229-230$.

Scherer, A.G., and G. Palazzo. 2011. The new political role of business in a globalized world: A review of a new perspective on CSR and its implications for the firm, governance, and democracy: Political role of business in a globalized world. Journal of Management Studies 48 (4): 899-931.

Shearman, D., and J.W. Smith. 2007. The climate change challenge and the failure of democracy. London: Praeger.

Taneja, S.S., P.K. Taneja, and R.K. Gupta. 2011. Researches in corporate social responsibility: A review of shifting focus, paradigms, and methodologies. Journal of Business Ethics 101 (3): 343-364.

Tempels, T., V. Blok, and M. Verweij. 2017. Understanding political responsibility in corporate citizenship: Towards a shared responsibility for the common good. Journal of Global Ethics 13 (1): 90-108.

Uhlaner, L., M. Wright, and M. Huse. 2007. Private firms and corporate governance: An integrated economic and management perspective. Small Business Economics 29 (3): 225-241.

WCED 1987. Our Common Future, United Nations General Assembly, Report of the World Commision on Environmenta and Development (www.un-documents.net/wced-ocf.htm (last visited August 20, 2018)) .

Whyte, J. 2013. The king reigns but he doesn't govern'. Thinking sovereignty and government with Agamben, Foucault and Rousseau. In Giorgio Agamben. Legal, political and philosophical perspectives, ed. T. Frost. London/New York: Routledge.

Zwier, J., and V. Blok. 2017. Saving earth: Encountering Heidegger's philosophy of technology in the Anthropocene. Techne: Research in Philosophy and Technology 21 (2-3): 122-142.

Publisher's Note Springer Nature remains neutral with regard to jurisdictional claims in published maps and institutional affiliations.

Vincent Blok is associate professor at the Business Management \& Organization Group and the Philosophy Group, Wageningen University (The Netherlands). In 2005 he received his $\mathrm{PhD}$ degree in philosophy at Leiden University with a specialization in philosophy of technology. Together with a research group of 4 post-docs and 6 $\mathrm{PhD}$ students, Blok is involved in several (European) research projects at the crossroads of Business Ethics, Philosophy of Technology and Responsible Innovation. His books include Ernst Jünger's Philosophy of Technology. Heidegger and the Poetics of the Anthropocene (Routledge 2017); Heidegger's Concept of Philosophical Method: Innovating Philosophy in the Age of Global Warming (Routledge 2019). Blok's work appeared amongst others in Business Ethics Quarterly, Journal of Business Ethics, Business Ethics: a European Review and Business and Society. See www.vincentblok.nl for more information about his current research. 